INTERPRETATION, LAW AND THE CONSTRUCTION OF MEANING 


\title{
INTERPRETATION, LAW AND THE CONSTRUCTION OF MEANING
}

Collected Papers on Legal Interpretation in Theory, Adjudication and Political Practice

\author{
by \\ ANNE WAGNER \\ Université du Littoral Côte d'Opale, \\ Boulogne-sur-Mer, France \\ WOUTER WERNER \\ Institute of Public International Law, \\ Vrije Universiteit, \\ Amsterdam, \\ The Netherlands \\ and \\ DEBORAH CAO \\ Griffith University, Australia
}

\section{算 Springer}


A C.I.P. Catalogue record for this book is available from the Library of Congress.

ISBN-10 1-4020-5319-3 (HB)

ISBN-13 978-1-4020-5319-1 (HB)

ISBN-10 1-4020-5320-7 (e-book)

ISBN-13 978-1-4020-5320-7 (e-book)

Published by Springer,

P.O. Box 17, 3300 AA Dordrecht, The Netherlands.

www.springer.com

Printed on acid-free paper

\section{All Rights Reserved}

(C) 2007 Springer

No part of this work may be reproduced, stored in a retrieval system, or transmitted in any form or by any means, electronic, mechanical, photocopying, microfilming, recording or otherwise, without written permission from the Publisher, with the exception of any material supplied specifically for the purpose of being entered and executed on a computer system, for exclusive use by the purchaser of the work. 


\section{CONTENTS}

BIOGRAPHICAL NOTES.......................................................................vii

INTRODUCTION.........................................................................................

PART I: LEGAL THEORY

\section{CHAPTER 1}

LAW AS FACT, LAW AS FICTION:

A TRIPARTITE MODEL OF LEGAL COMMUNICATION ................................ 3

\section{CHAPTER 2}

LEXICAL INDETERMINACY:

CONTEXTUALISM AND RULE-FOLLOWING IN COMMON LAW

ADJUDICATION

\section{CHAPTER 3}

TOPICAL JURISPRUDENCE:

RECONCILIATION OF LAW AND RHETORIC

\section{CHAPTER 4}

Legal Speech ACts as IntersubJective CommunicAtive

ACTION

\section{PART II: JUDICIAL REASONING}

\section{CHAPTER 5}

Who NeEds Fact When You've Got NarRative? The CASE OF P,C\&S VS UNITED KINGDOM

\section{CHAPTER 6}

TAKING FACTS SERIOUSLY 109

\section{CHAPTER 7}

TRANSFORMING AMBIGUITY INTO VAGUENESS IN LEGAL INTERPRETATION

\section{PART III: APPLICATION OF LAW IN POLITICAL PRACTICE}

\section{CHAPTER 8}

The InCLuSIVE/EXClusive NATION: BLACKS AND INDIGENOUS PEOPLES IN THE CONSTRUCTION OF THE NATION IN COLOMBIA 


\section{CHAPTER 9}

Global VALUeS AND FloAting Borders IN THE BRAZILIAN AMAZON .....

CHAPTER 10

LANDMARKS FOR ABORIGINAL LAW IN AUSTRALIA .............................195

REFERENCES........................................................................................205 


\section{BIOGRAPHICAL NOTES}

Moshe AZAR is Professor of Hebrew language and linguistics at the University of Haifa, Israel; member of The Academy of the Hebrew Language; Ph.D. in Linguistics, University of Nancy, France. His writing includes books (Language of Commitment in the Old Testament and the Mishna (in Hebrew); The Syntax of Mishnaic Hebrew (in Hebrew)) and articles on Hebrew syntax, semantics, and pragmatics. In recent years, he became interested in pragmatic interpretation of legal texts.

Clive BALDWIN is Senior Lecturer in Dementia Studies at the University of Bradford. Having trained as a social worker and been employed in community development he completed his $\mathrm{PhD}$ at the Department of Sociological Studies, University of Sheffield in 2000. His thesis focused on the competing narratives of innocence and guilt in cases of alleged Munchausen syndrome by proxy. He has since presented at national and international conferences on the narrative disparity between professional and lay accounts in such cases, and how this disparity can lead to wrongful or unreliable investigations and court judgements.

Farid BENAVIDES is a Colombian Lawyer, specialist in Human Rights and International Humanitarian Law. He studied Sociology of Law at the University of Barcelona and currently he is a $\mathrm{PhD}$ Candidate in Political Science at the University of Massachusetts. His Dissertation is about indigenous peoples and indigenous rights in Colombia.

Dr Deborah CAO is a Senior Lecturer affiliated with the School of Languages and Linguistics and the Socio-Legal Research Centre of the Law School, Griffith University, Australia. She was educated in China and Australia in interpreting/translation, linguistics, and law. She has published in the areas of legal translation and philosophical and linguistic analysis of Chinese law and legal culture. Her books include Chinese Law: A Language Perspective (Ashgate, 2004) and the forthcoming Translating Law.

Ross CHARNOCK, after first degrees in Exeter (UK), took his doctorate in linguistic pragmatics in Paris during the early $80 \mathrm{~s}$, under O. Ducrot. He is now senior lecturer at the University of Paris, where he teaches language for specialists of other disciplines, with a particular interest in the language of the law. Within this field, he specialises in the rhetorical and semantic analysis of common law judgments. He also has research interests in pragmatics and argumentation as applied to language teaching and testing, and continues to publish regularly on classical music for strings. 
Maarten HENKET received his law degree in 1972 at Amsterdam University. He has taught law, legal philosophy and legal writing at Utrecht University until his retirement in 2005. His main research areas within the wide field of legal semiotics are argumentation theory, including logic and rhetoric, and legal pragmatics.

Agnes SCHREINER is Lecturer at the Law Faculty, University of Amsterdam, studied law and lectures on several themes of the General Jurisprudence. She has specialized in a series of subjects associated with law: media, arts including rituals, semiotics and social sciences. See for instance The Semiotics of Digital Law (2004) and her 2003 free of charge web-edition The Ritual Manifesto (www.1001publishers.com/index_uk. $\mathrm{html})$. She researches legal cultures of Australia and of Europe. Recent publications on these cultures include Observing the differences (2004) and The Common Core of Trento. A Socio-Legal Analysis of a Research Project on European Private Law (2004).

Anita SOBOLEVA graduated from the philological faculty of the Moscow State University in 1986 and from the Moscow Law Institute in 1991. She holds an LL.M. in comparative constitutional law from the Central European University (Budapest) and a Ph.D. in linguistics from the Moscow State University (Russia). She is the author of numerous articles on the philosophy of law, legal rhetoric, legal reasoning and linguistic rights of minorities in Russian legal journals. In 2002 she published a book Topical Jurisprudence (in Russian). She is a member of the Bar Association and currently works as an Executive and Legal Director of a not-for-profit organization "Lawyers for Constitutional Rights and Freedoms" and is involved in human rights, civil liberties and public interest law litigation.

Dr. Hanneke VAN SCHOOTEN is a senior researcher at the Centre for Legislative Studies of Tilburg University, the Netherlands. Among her books are Regulering in de Rechtsstaat (1998), Semiotics and Legislation (ed. 1999), Recht naar binnen kijken. Een toekomstverkenning van huisrecht, lichamelijke integriteit en nieuwe opsporingstechnieken (with B.J. Koops and M. Prins, 2004). Her articles include 'The Meaning of Law as Instrument' (1996), 'Freedom of Expression: Censorship and Sense Construction' (2003), 'On War, Peace and Armed Conflict' (2004), 'A New Conceptual Framework for Analysing a Case Study on ICT and the Sanctity of the Home' (2004), all published in the International Journal for the Semiotics of Law. 
Dr. Pekka VIRTANEN is a social scientist (international relations and anthropology). He has worked extensively in Africa and recently also in Brazil, where he has participated in various research projects and development co-operation activities. His research interests include identity politics, legal pluralism, the role indigenous institutions in natural resource management, and international environmental regimes - especially marketbased normative mechanisms.

Anne WAGNER is a Senior Lecturer in LSP affiliated with the Université du Littoral Côte d'Opale, France. She is the deputy Editor-in-Chief and the French Book Review Editor of the International Journal for the Semiotics of Law (Springer). She is the president of the International Roundtable for the Semiotics of Law (IRSL). Her main research interests include legal language, law and semiotics, legal translation, plain language, interpretation, contemporary legal theory, law and literature, legal history. She is the author of La Langue de la Common Law (L'Harmattan 2002), and has recentely co-edited The Feminine in Legal Discourse (special issue of The International Journal for the Semiotics of Law 19/2, 2006), as well as three books entitled Contemporary Issues in the Semiotics of Law: Cultural and Symbolic Analyses in a Global Context (Hart 2005), Images in Law (Ashgate 2006) and Legal Language and the Search for Clarity: Practice and Tools (Peter Lang 2006).

Wouter WERNER is Professor of public international law at the Vrije Universiteit, Amsterdam. His main fields of interest are the theory of international law and the legal regime regulating the use of force in international relations. 


\section{INTRODUCTION}

\section{ANNE WAGNER, WOUTER WERNER AND DEBORAH CAO}

Semiotic theories have emphasized the contextual and dynamic nature of meaning and knowledge. As one of the founding fathers of semiotics has argued, all meaning emerges in a triadic structure, where a 'sign stands for an object, not in all respects, but in reference to a sort of idea ... the ground'. ${ }^{1}$ This understanding of the construction of meaning rules out the possibility of a fixed foundation of knowledge. All knowledge is mediated by a sign, which can only be interpreted by reference to yet another sign, its ground. In the same fashion, legal semiotics has emphasized the dynamic character of legal concepts and stressed the importance of interpretation and the construction of meaning. In response to new problems, changing power structures, changing societal norms and new faces of injustice, established doctrines are reconsidered, reformulated and partly replaced by competing doctrines and hypotheses. ${ }^{2}$

The open and conjectural nature of legal knowledge raises some foundational questions regarding the nature and function of law. How is, for example, the openness of legal rules to be reconciled with the quest for final authority? Who has the power to define words and concepts in a concrete case? How is the construction of meaning in law affected by societal discourses? Such questions are closely related to the central topic of this volume: the problem of legal interpretation and the construction of meaning within and through law.

The contributions to this volume are based on a selected number of papers that were presented at the 2004 International Roundtable for the Semiotics of Law in Lyon. The contributions reflect the connectedness, as well as the diversity, of the community of legal semioticians. While all contributions deal with issues of interpretation and the construction of meaning, the fields of application as well as the theoretical underpinnings of the contributions are broad. We hope that this 'diversity in unity' will contribute to a fruitful discussion on the foundations and application of semiotic theories of law.

${ }^{1}$ Charles Sanders Peirce, Collected Papers (Cambridge: Harvard University Press, 1931-1935), Vol. II, at 34.

${ }^{2}$ See for an analysis of the dynamics of law and legal interpretation Roberta Kevelson's seminal work, The Law as a System of Signs (New York: Plum Press, 1988). 
Part I of this volume discusses the problem of legal interpretation from a more general, theoretical perspective. The four chapters in this part discuss the topic of legal interpretation from different, yet overlapping perspectives: institutionalism (van Schooten), contextualism (Charnock), legal rhetoric (Soboleva) and communicative rationality (Cao). All four chapters explicitly relate the problem of interpretation to the notion of intersubjectivity and emphasize that legal interpretation is embedded in wider social practice. Thus, van Schooten examines the importance of common societal beliefs that shape the law to law and structure the interplay between legal rules, the application of those rules and social interaction. In a similar fashion, Charnock criticizes the literal rule of construction and argues that the content of legal rules is established by consensus in the relevant community. Soboleva sets out how topoi, or commonplaces, guide legal reasoning and function as constraining and disciplining structures. Finally, Cao takes up the Habermassian notion of communicative rationality to explain legislative and judicial acts. By contrast to approaches to (legal) speech acts that derive meaning primarily from intention, Habermas stresses the importance of intersubjectivity and acceptability, thus echoing the Piercian reading of the relation between the construction of meaning, intersubjectivity and rationality. ${ }^{3}$

The notion of intersubjectivity also figures prominently in Part II of this volume that deals with the problem of interpretation in judicial reasoning. In Chapters Five, Six and Seven, Baldwin, Henket and Azar, discuss respectively one of the most delicate topics related to the application and interpretation of law: the construction of legally relevant facts in legal proceedings. In several respects, Baldwin and Henket take different positions towards the role and construction of facts in legal proceedings, as may be inferred from the respective titles of their contributions: 'Who needs fact when you got narrative?' (Baldwin) and 'Taking facts seriously' (Henket), whereas Azar, in his paper, approaches judicial reasoning from a different angle: in terms of ambiguity and indeterminacy ${ }^{4}$ where law and language often intercept. Indeed, Azar

${ }^{3}$ See for example Habermas's discussion of Pierce in J. Habermas, Texte und Kontexte, Suhrkamp (Frankfurt: a.M., 1991).

${ }^{4}$ For more information, see L. Solan, "Vagueness and Ambiguity in Legal Interpretation', 73-96, in J. Engberg, M. Gotti, V. Bhatia and D. Heller (eds.), Vagueness in Normative Texts (Bern: Peter Lang, coll. Linguistic Insights, 2005), vol. 23, A. Wagner, 'Semiotic Analysis of the Multistage Dynamic at the Core of Indeterminacy in Legal Language', 173-200, in J. Engberg, M. Gotti, V. Bhatia 
insists that these are crucial features in legal discourse analysis where the role of 'de-vaguefying' or 'desambiguation' still remains crucial for the interpreters. Azar argues that judges tend to adopt an anti-pragmatic approach in such disputed cases treating them as cases of vagueness instead of what they actually are, that is, cases of ambiguity. In their contributions, Baldwin and Henket give concrete analyses to legal interpretation and both agree on two important points. First, judges and juries base their decisions on the most convincing narrative of facts - on narrative coherence rather than on 'correct representation' as such. Second, such a semiotic understanding of judicial practice does not rule out the possibility of critique. Notions such as due process, communicative rationality or accuracy do not lose their meaning in non-positivistic readings of judicial reasoning.

Part III of this volume takes up the interplay between law and globalization and the role of law in (international) politics and thus touches upon the question of who is able to define legal words and concepts in concrete circumstances. The power to define has played a crucial role in the formation of Latin-American States, as the contributions of Benavides Vanegas and Virtanen demonstrate.

Benavides Vanegas discusses how the fight for independence, as well as the conceptualization of 'the nation', in Colombia was shaped by the 'coloniality of power' and the dominant European legal and political concepts. The initial struggles for independence, Benavides Vanegas argues, should be interpreted as struggles for equality within the Spanish nation, while the later process of nation building was based on a logic of inclusion and exclusion that can only be understood in terms of predominant racial definitions and hierarchies. Without a proper understanding of the coloniality of power, current discussions on nationalism in the era of globalization start from the wrong place. The chapter by Virtanen shows how in the Brazilian Amazon, economic globalization and integration in an authoritarian central State have reshaped local cultures and disciplined local populations. However, Virtanen's

and D. Heller (eds.), Vagueness in Normative Texts (Bern: Peter Lang, coll. Linguistic Insights, 2005), vol.23.

James B. White, The Legal Imagination: Studies in the Nature of Legal Thought and Expression (Boston/Toronto: Little Brown, 1973), Brian Bix, 'Can Theories of Meaning and Reference Solve the Problem of Legal Determinacy?' (2003) Ratio Juris 16: 281-295. 
chapter also warns against simplistic, unidirectional interpretations of the process of globalization. Based on Lotman's semiotics of borders and identity, Virtanen argues that 'current international relations are characterized by interpenetration of different normative systems' and could in some areas - such as international certification - lead to 'interesting alternative(s) to the prevalent forms of unidirectional and homogenising globalization.' Agnes Schreiner, on the other hand, deals with the willingness of Aborigines to demonstrate the struggle for their rights and their 'traditional connection to the land' in Australia, analyzing their art of memory which is 'a big play of combinatorial exchanges'. She insists on, and grounds this argument, in the deep semiotic analyses of two particular landmarks, i.e., the Manggalili and the Djarrakpi. 